\title{
The influence of ideology on black African students' perceptions of the University of KwaZulu-Natal's bilingual policy
}

\section{Nolwandle MaDumisa Madlala}

Discipline of Psychology, School of Applied Human Sciences, University of KwaZulu-Natal, Pietermaritzburg, South Africa

1wandle.dumisa10@gmail.com

https://orcid.org/0000-0002-4411-3969

\section{Nhlanhla Mkhize}

Discipline of Psychology, School of Applied Human Sciences, University of KwaZulu-Natal, Howard College Campus, Durban, South Africa

mkhize@ukzn.ac.za

https://orcid.org/0000-0002-0088-5780

(Received: 13 February 2019; accepted: 2 August 2019)

\section{Abstract}

The authors' chosen theoretical framework posits that how black students perceive bilingual instruction in higher education is largely influenced by the various ideological perspectives they have been socialised into in different contexts where African languages are used, and continue to be diminished, for different objectives. Through individual interviews, the study explored which ideological frameworks participants drew on when discussing their general perspectives on, as well as perceived benefits and challenges of, bilingual instruction at the University of KwaZulu-Natal. They were also asked what their recommendations for the policy's implementation process were. The students who had experienced bilingual instruction explained how they started better understanding the content of their studies as well as the meaning of previously difficult English concepts. Students who had not experienced bilingual instruction mainly discussed how they thought the use of isiZulu could facilitate better understanding primarily for students who struggle to understand English. However, they warned that an extended use of isiZulu would hinder upward socioeconomic mobility for graduates who struggle to communicate in English. In light of the study's findings and the conflicting ideologies shared in South Africa, the authors recommend that when planning their respective implementation processes for bi/multilingual instruction for higher education, national and institutional policymakers should consider students' various ways of perceiving languages' differential levels of use and esteem and how this could influence their conceptions of academic objectives.

Keywords: higher education, transformation, conflict, ideologies, value, mobility 


\section{Introduction}

In 2006, the University of KwaZulu-Natal (UKZN) included isiZulu as an official institutional language alongside English in its policy (UKZN, 2014). The changes outlined therein are in line with the recommendations the democratic government makes for South African public institutions of higher education (hereafter SAPIHEs) in its revised language policy for higher education. In this policy, government encourages all SAPIHEs to develop at least one of the most spoken indigenous South African languages (hereafter ISALs) in their respective provinces for use as a language of instruction and institutional communication alongside English (Ministry of Education, 2002). These reformation processes are hoped to create a more pedagogically and democratically sound higher education system in South Africa by producing graduates with equitable levels of academic comprehension and multilingual proficiency across races. As it stands, with English language teaching not based on evidence-based pedagogical theories of additional language teaching in black public schools, the language has been found to be a major barrier to some students' epistemological access and is thus perceived to be one of the main reasons behind black students having the highest failure and drop-out rates, while white students have the highest success and participation rates (Council on Higher Education, 2015; Heugh, 2000; MacDonald, 1990; Masitsa, 2004; Setati, Adler, Reed, \& Bapoo, 2002). Given that this racial inequality was the objective behind the colonial and apartheid government's design of racially separated and unequal education systems (Alexander, 2001; Department of Bantu Education, 1962; Elliott \& Gurrey, 1940; Reagan, 1987; van Dyk, 1967), the fact that these systems are still in use 25 years into a politically democratic era is considered to be unjust (Phillipson, 1996; SkutnabbKangas, 2009). To genuinely decolonise and democratise education and socioeconomic systems will require changing teaching and learning processes to be more pedagogically sound, and for all citizens (young and old) to have racially and linguistically appropriate access to participate in any public system in the country (Constitution of the Republic of South Africa, 1996; Ministry of Education, 2002; UKZN, 2013, 2014).

Chetty (2013), Taunyane (2013), and Rudwick (2015) reported that the majority of UKZN stakeholders are resistant to, and frustrated by, the advancement of language reform at the institution. Additionally, Chetty (2013) and Rudwick and Parmegiani (2013) reported that most of the black isiZulu-speaking students they interviewed for their respective studies insisted that English should remain the main language of higher education because it is the only language that can be more widely used in academic and professional national and international contexts. These frustrations should raise concern for UKZN's management given that resistance from students could hinder full implementation of the bilingual policy. Resistance could also force management to reverse the changes altogether, in the same way that the apartheid government had to reverse the elevation of Afrikaans as language of tuition in black schools after the 1976 student protests and subsequent massacre (Figone, 2012). Deduced from Figone's (2012) notions, this paper suggests that for UKZN's revised language policy to have a chance of successful adoption, its students need to be willing to learn in isiZulu; those who do not know the language need to be willing to learn it and learn in it, and potential students need to be willing to apply to study at the institution. If students perceive 
isiZulu as a hindrance to the attainment of what they deem a desirable higher education, they could either protest against its inclusion or simply leave or avoid the institution (Figone, 2012). As evidenced by the Soweto student uprising against Afrikaans in 1976, and by recent national Fallist (\#FeesMustFall and \#RhodesMustFall) protests in various SAPIHEs, South African students are capable of rioting against what they do not want in their institutions, and government and institutional managements have been known to accommodate them (Figone, 2012; Makhele, 2016). If SAPIHEs' language policies are dictated by students who are opposed to the wider integration of ISALs in teaching and learning processes, academic language barriers may continue to deny black South African students deeper epistemological access, and prevent the decolonisation and democratisation of the higher education system.

If one systematically compares the way arguments in support of, and against, the use of ISALs in higher education are differentially presented, the opposing ideological beliefs that underpin each side become clearer. Arguments for the inclusion of ISALs generally aim to highlight pedagogical theories about the role of language in learning as well as the tenets of a truly decolonised and democratic state (Cummins, 1980, 2000; Heugh, 2000; NdimandeHlongwa, Balfour, Mkhize, \& Engelbrecht, 2010; Skutnabb-Kangas, 2009). Arguments against the inclusion of ISALs, including those of black South African higher education students, seem to echo utterances of the colonial and apartheid eras (Alexander, 2001; Department of Bantu Education, 1962; Elliott \& Gurrey, 1940; Reagan, 1987; van Dyk, 1967). In instances where black students are reported to be in opposition to receiving formal education in ISALs, some still agree that when they do receive explanation of a difficult academic concept in their home language they find it easier and quicker to understand because it is being explained in vocabulary that they can more readily relate to and contextualise (Chetty, 2013; Dalvit \& de Klerk, 2005). Additionally, Fallist protests show that black students are aware that the Western-based education system is still largely oppressive and exclusionary (Figone, 2012). Despite this, when it comes to propositions of them learning in languages that are more pedagogically appropriate and that they can thus understand better, they reject these on the basis of those languages seeming to be inadequate for their social and economic aspirations (Chetty, 2013; Dalvit \& de Klerk, 2005; Rudwick, 2015; Taunyane, 2013).

The aim of the study summarised in this article was to explore UKZN students' perceptions of the bilingual policy, and of bilingual instruction at the institution, in order to gain insight into the ideologies that they in particular drew on to contextualise their perspectives. It is hoped this will give policymakers a clearer understanding of the foundations of students' frustrations, and how to better facilitate negotiations by acknowledging the importance of students' fears and concerns in addition to their attempts to inform the latter of the need for linguistic transformation. This article starts by briefly describing the rationale provided in government's and UKZN's language policies, as well as some of the reported reactions to these. This is followed by an overview of the study's theoretical framework and methodology, ending with a brief discussion of the findings and recommendations for future sociolinguistic and psychological research pertaining to the national and institutional language policies for higher education. 


\section{The decolonisation and democratisation plans for South African higher education}

In South Africa, until the democratic government came into power in 1994, the choice of the language of tuition used in the different phases of education had been in the hands of a white racially oppressive government. Its main aim in providing black South Africans with an inadequate formal education was to ensure that those black South Africans remained inferior to their white counterparts academically, economically, and socially. In elevating the status of the apartheid government's own Western languages and ensuring their dominance, the state put much effort into marginalising and suppressing ISALs (Department of Bantu Education, 1962; Elliott \& Gurrey, 1940; Reagan, 1987; van Dyk, 1967). Studies conducted in the colonial and apartheid eras found that learning in a foreign Western language hindered epistemological access for black students, but the white government ignored this in favour of elevating the use and esteem of Western languages and their speakers (Department of Bantu Education, 1962; Elliott \& Gurrey, 1940; Reagan, 1987; van Dyk, 1967).

With the realisation of democracy in 1994, the new government started amending its predecessors' discriminatory policies in an effort to elevate the livelihoods of previously oppressed people to be on a par with their more privileged and esteemed fellow citizens. At the extreme end of this dichotomy are black South Africans who, at the time of this study, consisted roughly $80 \%$ of the population but had the lowest rates of academic and socioeconomic participation and success (Constitution of the Republic of South Africa, 1996; Council on Higher Education, 2015; Ministry of Education, 2002; Statistics South Africa, 2013). In the public education sector specifically, government has facilitated the inclusion of all races in institutions where they were previously excluded by whites. Before this, academic institutions had been reserved for different race groups according to the quality of education they were mandated and equipped to provide (Department of Bantu Education, 1962; Ministry of Education, 2002). Additionally, after continuing to observe a consistent trend of racial differences in academic performance between white and black South African students in SAPIHEs (Council on Higher Education, 2001, 2015), and because language of tuition had over the centuries been identified as one of the main barriers to academic success for black students, the Ministry of Education (2002) amended the national language policy for higher education to be in line with the goal towards transformation. This aims to ensure meaningful participation by black students, so that they are not limited to just being physically present in their academic institutions (Heugh, 2000; Ministry of Education, 2002; Skutnabb-Kangas, 2009; UKZN, 2014). As an equally imperative contribution towards social transformation, government also posits that, by including ISALs in higher education, educators and students who do not know these languages can have the opportunity to become multilingually proficient and be equipped to teach and learn in their respective province's multilingual contexts. This could lead to speakers of different languages being able to communicate meaningfully in various contexts in this multilingual and multiracial country, including various social and economic contexts - especially with the majority of the population who 
remain excluded from meaningful participation (Heugh, 2000; Ministry of Education, 2002; UKZN, 2014).

A number of studies have reported higher education students' reactions to this recommended inclusion of ISALs in different institutions across the country (Chetty, 2013; Dalvit \& de Klerk, 2005; Paxton, 2009; Rudwick, 2015; Taunyane, 2013). UKZN students interviewed by Taunyane (2013) were resistant to the possibility of learning isiZulu, suggesting that learning a language that will not contribute to their degree was unnecessary, and that learning ISALs should rather happen in pre-primary and primary schools. Rudwick (2015), whose research explored language dynamics and ideological constructions in South African higher education, found that the introduction of the compulsory isiZulu course at UKZN had alienated some students and staff at the institution. Some of the isiZulu lecturers reported that their students were resistant, and they themselves saw the teaching of the course as an impractical and useless exercise. Some even likened it to the apartheid regime's attempt to force black students to learn Afrikaans, which resulted in the infamous massacre. Rudwick (2015) also argued that imposing isiZulu in this way upon lecturers and students at UKZN seems to have ideological and political motives rather than a pedagogical one; she suggested that learning ISALs should rather be fostered in primary and secondary schools, and that trying to force it in higher education is too late.

Other SAPIHEs seem to be facing similar social dynamics as UKZN. A study conducted by Dalvit and de Klerk (2005) at the University of Fort Hare found that students insisted that they needed to learn English in an academic context and to learn primarily in English because it is the language of power and development, nationally and internationally. The students suggested that an education in their indigenous home languages would be useless to them because they would not be able to share their knowledge, no matter how vast, with anyone except people who can also speak their language. This would mean that they would not be able to find work - neither in regions of South Africa where their language is not spoken, nor internationally. But, when it came to pedagogical considerations, the same students insisted that the use of their home languages facilitated the understanding of subject content.

However, they pointed out that this would only be necessary for junior undergraduates who still needed to get used to the higher education system because, once they progressed in academic years, learning English and learning in English became more essential (Dalvit \& de Klerk, 2005).

At the University of Cape Town, Paxton's (2009) participants relayed a more positive perspective. Her study explored the perspectives of isiXhosa students who had participated in a multilingual glossary project at the institution, in which they had the opportunity to discuss economic concepts in isiXhosa, their home language. In a discussion of their experiences, the students suggested that learning in their home language facilitated their understanding of subject content. They said that this was different to experiences of learning in the more unfamiliar English language, which sometimes brought challenges of not understanding the vocabulary used and thus not understanding the content they were trying to gain knowledge of. These students revealed that in their own study groups, comprised of speakers of the same 
language, they often translated difficult sections into their own home language, and discussed their assumed meanings in it. They pointed out that if they could not figure out the meaning of the English content in their home language, they would resort to memorising the English terms and paragraphs in order to reproduce them verbatim in formal assessments (Paxton, 2009). Paxton (2009) cautioned that when students translate their academic work into their own languages by themselves, they run the risk of coming up with inaccurate definitions. Paxton (2009) suggested it would be more academically sound for educators to do the translations instead. This would ensure that what students learn in any language is standardised and accurate.

A few studies conducted in other African countries demonstrated that the educational challenges posed by inadequate proficiency in the language of tuition, for students for whom it is an additional language, are not unique to South Africa. A number of these countries are introducing indigenous languages as languages of tuition alongside the European languages introduced by colonial leaders, in an effort to overcome the residue of the colonial education system (Adegbite, 2003; Akinnaso, 1993; Bunyi, 1999; Kyeyune, 2003). Not all seem to welcome these initiatives. Adegbite (2003) suggested that the current dominance of English over Nigerian indigenous languages is a result of the Nigerian elite's positive attitude towards English and its negative attitude towards the country's home languages because English serves the elite's interests of social and economic advancement. He further suggested that the perceptions of the Nigerian public are influenced by those of the elite because the latter is responsible for policy-making in the country and is perceived to be serving public interest. Thus, both the literate and pre-literate in Nigeria express a preference for learning English and learning in English over their home languages. Adegbite (2003) pointed out that Nigeria is plagued by underdevelopment in the education sector, with illiteracy and a lack of communication skills further perpetuating the inability of some citizens from participating fully in other national activities, such as political processes. He cautioned that the inadequate use of the more familiar indigenous African languages in education may maintain the divide between the elite and the uneducated masses, especially with future generations because some parents prevent their children from learning in their home languages in preference of the acquisition of English (Adegbite, 2003).

\section{Theoretical framework: The influence of socially shared constructions of language and privilege in South Africa}

The argument put forward in this paper is that interpretations of current conflicting perspectives on the choice of language in higher education should consider that these perspectives are contextualised within the linguistic ideologies of the country's sociopolitical past, present, and future endeavours. Neither side of these arguments should be dealt with as mutually exclusive and as void of ideological influence in discussions of language in education. The fact that languages in South Africa are not just mediums of communication and representation, but are also used to facilitate and hinder access to various contexts, continues to obstruct efforts towards transformation in the country (Alexander, 2001; Heugh, 
2000; Phillipson, 1996; Skutnabb-Kangas, 2009). Pedagogy and socioeconomic aspirations should be acknowledged as intertwined, and their relationship should be used to facilitate efforts towards educational and wider transformation in the country rather than be presented as two opposing factors. In contextualising current perspectives, one first has to have a clear understanding of the pedagogical role of languages and know how this was acknowledged but blatantly dismissed by the colonial and apartheid governments in designing an education system for black South Africans based primarily on the aim of socioeconomic racial inequality (Alexander, 2001; Department of Bantu Education, 1962; Elliott \& Gurrey, 1940; Reagan, 1987; van Dyk, 1967). This understanding can then potentially facilitate a consequential understanding of how socioeconomic transformation also requires previously ignored pedagogical justice (Alexander, 2001; Heugh, 2000; Phillipson, 1996; SkutnabbKangas, 2009).

\section{Methodology}

All study procedures were conducted by the first author, under the supervision of the second author. Before commencing, ethical clearance was obtained from the institution's Gatekeeper as well as the Humanities \& Social Sciences Research Ethics Committee. The research was informed by a qualitative paradigm, which seeks to understand phenomena in the contexts in which they occur, and from a subjective point of view (Guba \& Lincoln, 1989; Silverman, 2005; Terre Blanche, Kelly, \& Durrheim, 2014). Within the qualitative paradigm, perspectives explored in this study were situated within the interpretive theoretical framework, which locates and interprets them within their social, cultural, and historical contexts (Guba \& Lincoln, 1989; Terre Blanche et al., 2014). The sample consisted of 11 black African students from UKZN's Pietermaritzburg campus in South Africa, where the first author was registered as a master's student. They included South African students as well as students from other African countries. In addition, three black isiZulu-speaking South African students were sampled from UKZN's Edgewood campus because that is where the only fully bilingual honours class was offered at the time of data collection.

The snowball sampling technique was employed to enlist participants. This is a nonprobability sampling technique that is used to identify potential participants, based on the conceptual framework and objectives of the study - those participants identified initially, are then asked to refer the researcher to participants from the same contexts as themselves (Silverman, 2005). In this particular study, the final sample was collected based on literature and language policy suggestions that, as black students, they are the sub-category of students who have been and continue to be most affected by language choice in education on the continent (Alexander, 2001; Cummins, 1980, 2000; Heugh, 2000; Ministry of Education, 2002; Paxton, 2009; Phillipson, 1996; Skutnabb-Kangas, 2009). To gather the sample, the first author approached students as they were walking around campus and asked if they would be willing to participate in a single confidential interview about their perceptions of the institution's bilingual policy. Those who agreed gave their contact details to the researcher, and a time and private place were agreed upon for their interview. After each interview, the participants were asked to refer the researcher to other students who might be 
interested. The sample size was not predetermined; the researcher sampled to the point of information redundancy, which is when new interviewees seem to be mentioning the same issues as previous interviewees, and no new critical information is arising (Silverman, 2005). A semi-structured interview schedule guided the confidential one-on-one discussions, which were recorded after gaining informed consent from each participant (Silverman, 2005).

Data analysis began from the first interview. An advantage of using a semi-structured interview is that you can also ask follow-up questions like, "please elaborate on that" or "what do you mean by "they think you are better?"” in order to gauge clearer responses that cannot easily be misinterpreted during data analysis. Theoretically relevant issues raised by each participant were noted by the researcher and explored with that participant as well as with subsequent participants. All the audio tapes were transcribed by the researcher during the data collection period. Notes made during the interviews were also summarised on each transcription (Braun \& Clarke, 2006; Silverman, 2005). All interviews with participants who had an English-only learning experience at the university were conducted mostly in English as per their preferences, with only a few terms uttered in isiZulu, which the researcher typed out verbatim with translations in brackets next to them. The participants from the bilingual honours class each asked to be interviewed in isiZulu after the researcher asked which of the two languages they preferred the interview to be conducted in. These interviews were also transcribed verbatim. The extract selected as example for the discussion of findings has been presented verbatim, followed by the English translation. The researcher employed thematic analysis, following Braun and Clarke's (2006) six-phase guide, to identify patterns within and across interviews; they stated that the key to identifying a theme is to ask whether it contains crucial information that answers one or all of the research questions. Although the guide to identifying these themes is in step-by-step form, the authors highlight that it is a recursive process, where an analyst can move between different steps as needed, and not necessarily in a linear or circular fashion.

\section{Discussion of findings}

For purposes of identification, the isiZulu speaking participants who had experienced bilingual tuition are represented by the letters "BZ," which stands for "bilingual Zulu." IsiZulu speakers who had had English-only tuition are represented by the letters "EOZ" (English-only Zulu). The non-isiZulu speaking participants who had only experienced English-only tuition are represented by the letters "EONZ" (English-only non-Zulu). Finally, the latter two groups of participants are represented by the letters "EO" (English-only) when grouped together. 


\section{Research Question 1: "What are UKZN black African students' general perspectives on the institution's isizulu/English bilingual instruction programme?"}

What became apparent in the participants' responses is that because learning in a language is intertwined with learning that language, how they perceived the social and economic roles of languages had a great influence on their choices for language of tuition.

\section{Perceptions of the usefulness and relevance of languages}

Participants tended to base their responses on their perceptions of the usefulness and relevance of languages in South Africa and internationally. Historically in South Africa, English was the language of the white people who had sole possession of the best privileges socially and economically, while being black meant that you were a poor menial labourer who was denied access to contexts of luxury (Reagan, 1987). The perspectives provided by the EO participants indicated that they still perceived access to the English language as synonymous with access to social and economic privileges and contexts of luxury, while they perceived knowledge of their own home languages as incapable of yielding socioeconomic benefits. They thus perceived English as the main skill that any black South African student should gain from acquiring an education.

EOZ4: Why come to university if you can't study in English?

EOZ2: Uhm, okay I think English in itself is a, it's a power language. If you know English very well, if you can speak English very well, you can write it very well it's good, uhm, you're at a level of power nje [just] just by being-when you know people that speak English very very well they are highly esteemed versus umuntu opatanisayo isiNgisi sakhe and you know oshawa uJoji [a person who struggles with their English and you know sometimes gets it wrong]. That person they actually become ridiculed by society just because they are not very affluent or their accent is not good enough. So English is a very powerful tool.

By contrast, the BZ participants appeared to be more concerned with how the intended level of use of isiZulu at UKZN would elevate its use, value, and relevance in the institution and wider society.

BZ1: Kuyenzeka ngoba izingane, akengithathe njengomzali ozozala ingane manje. Uzoyithatha lengane ayise esikoleni sabelungu noma sabamhlophe. Lapho esikoleni sabamhlophe uzofika afunde konke mayelana nolwimi lwesiNgisi, afunde amasiko, okubalwa kuyo inhlonipho, indlela yokuziphatha, ephathelene nje nosiko lwaseNtshonalanga. Uzobe eseyakhohlwa ngalolu olwakhe ngani ngoba akekho omgqugquzelayo, noma akekho omnakelelela ukuthi alukhulume, azi namasiko akhona, ahambhele nezindawo lezi zamagugu esintu akwaZulu. Kungenzeka kumshaye lokho, agcine nje esewele ngale unomphela, kulolu lwabamhlophe. 
[It does happen because children, let me take a parent who will give birth to a child now. They'll take that child to a school for white people. In that school, that child will learn everything associated with English, their traditions, amongst them being respect, how one should carry themselves, to do with just Western traditions. They will then forget their own, why because no one is encouraging them, or no one is taking care that they speak it, that they know their traditions, and that they go to places that showcase isiZulu treasures. That may damage them; they may end up crossing over to the other side for good, the white people's side.]

\section{Black South Africans are perceived based on their proficiencies in English}

The second perspective concerns what the EO participants described as the ways black South Africans are perceived based on their linguistic proficiencies. They mentioned how, in South Africa, black people are ranked socially, economically, and intellectually based on how well they communicate in English. They themselves appeared to use this same criterion to inform their perceptions of the type of students they described as the only ones who needed to be taught in isiZulu. They described isiZulu-speaking students from former black Department of Education and Training schools as most likely to struggle to understand academic content taught in English, making them the only type of students in need of remedial isiZulu tuition. They also stated that isiZulu-speaking students who appeared to be more proficient in English (presumably, those from former Model C schools) did not need to be taught in their home languages and shouldn't be forced to.

The EO participants described what is perceived as a good proficiency in English as a skill that gives society the impression that, as a black South African, you are capable of learning and performing well academically and, in addition, that you belong to a higher socioeconomic class. In contrast, the participants described a lack of proficiency in English as indicating that one battles to perform academically. Furthermore, this means that in the workplace, someone who has an inadequate proficiency in English will be perceived by employers and colleagues as having been unable to learn adequately, and who will therefore struggle to understand and perform tasks.

EONZ1: Well, I mean in the current situation, yes it does. Uh, because people, I don't know, have an association of [English] fluency with intelligence. I think we all do it. If someone's got a funny accent you're like, mhmm-you tend to doubt what they're saying.

Some participants even suggested that students who struggle to understand English at tertiary level are lazy, and need to make more of a personal effort to improve their language proficiency.

EOZ5: But I feel as though like, if you need to pass high school with that English then you can learn during varsity. I think we, like, it's making. I'm thinking most varsities like beebering [the participant meant to say "babying," as in treating them like babies] people. ... We're trying to make society so comfortable so that where everyone 
passes and everyone gets their degree but when people go out into the world then it's like, okay well, we're not equipped for this. So I feel as though like, we have to sort of strip away a few things. If people are struggling, I don't think we can accommodate that. I don't think we have to change the whole system to accommodate, just to accommodate for this particular time and then afterwards it's like, okay well you got your degree, goodbye, we're done.

Research Question 2: "What are the perceived benefits and challenges of bilingual instruction at the institution?"

\section{Benefits}

The primary possible benefit that was suggested by all the participants in this study was that including isiZulu throughout the institution could facilitate epistemological access for black isiZulu-speaking students.

BZ2: Well, studying in English, when you study in English eh-the first thing is the truth is that it's English and it's not our first language. Even if you do it as a first language in school, but the fact is you won't be like a white person, you won't be like anyone who was born with it as their first language.

The consequential benefit of this was perceived to be linguistic and social transformation. This includes the inclusion of indigenous South African knowledge systems in formal public knowledge systems that predominantly represent Western cultural and knowledge systems.

EONZ1: So for me I think, uhm, there's a lot of knowledge, coming from a scientific perspective, there's a lot of knowledge that is not necessarily documented because we don't have the words for it. But, learning now in isiZulu and English would allow those people to also document what they know, because it's not that African people haven't been doing anything - they have-it's just that they don't record stuff. This could be a platform, I think, for that. So I think that it has a purpose.

\section{Challenges}

The main challenge perceived by the EO participants as likely to result from the inclusion of isiZulu as a language of tuition is a decreased use of, and exposure to, the English language for black African students, which they perceived would result in them acquiring education with a diminished value. A second challenge, which was perceived by all the participants, is that because UKZN is a multilingual and multinational university, non-isiZulu speaking students are likely to experience challenges while attempting to learn, and learn in, isiZulu as a foreign language.

EONZ1: No 'coz that would mean that I'd have to start from the-from scratch? ... So, hmm, is it necessary? That that's the other question that you ask because I know that even in Russia, people who get scholarships to go to Russia or to go to China or to Cuba or whatever, the first question they ask themselves is: "Am I, am I prepared 
to learn another language?" You know, and: "Will my proficiency in that language affect the way I perform?" So I think that would be the challenge then.

Research Question 3: "What are their recommendations for the implementation of the bilingual policy at UKZN?"

The EO participants seemed to either not be sufficiently familiar with UKZN's bilingual policy, or had different interpretations of it. They expressed frustration with how they thought it was being, and would be, implemented.

EOZ3: [lets out a big sigh] I actually don't know how they are kinda conducting the whole thing. How, how is it happening?

EONZ5: And from my point of view, obviously I think that if a lecturer were to just switch to Zulu in the middle of the lecture I'd also be a little confused. . . . So I mean this, the whole point behind this, is to get everyone to start talking and everyone to say, you know-well, this is what I'm thinking, this is how I'm looking at it.

EONZ3: Mm, I think if anything the university should put out a, a memorandum, asking students and the teaching bodies_-give everyone the voice that we supposedly have, uhm, as opposed to decisions just being made. Uhm, and that will give us or give the s-us as in everybody who's on the ground level, the grassroots level, the choice and a feeling ... I think that's one of the problems, that the the grassroots levels are feeling alienated by the high ranks. Because these decisions are being made for them without consensus at the bottom. And they're affecting everybody at the bottom. And positive or negative is arguable. Uhm, but uh, that's yeah-maybe there should be an open forum that we have, and we can discuss, and for them to put across why they're doing it, clearly, so that everyone has the same perspective instead of people going and, like, creating these ideas of why they're doing it. So yeah. Yeah, consensus would be great.

Some of the participants, who had mentioned the benefit of isiZulu language development leading to linguistic and cultural preservation, also added that the university should work on improving students' perceptions of isiZulu. The BZ participants' main recommendation was that UKZN needed to direct greater focus on translating academic material from English to isiZulu.

\section{Conclusion}

To summarise, the study outlined in this article demonstrates that while the EO participants provided their perceptions and perspectives on language use in the higher education system specifically, they also appeared to be concerned with how society in general tends to assign black South Africans' academic statuses and socioeconomic categories based on their English accents. And the participants also stated that these societal perceptions also have a great influence on black South Africans' socioeconomic opportunities. This perceived 
socioeconomic association is regarded by the authors as most likely the main reason why all the EOZ participants seemed to distance themselves from black students who could be perceived as struggling to understand English and, therefore, in need of remedial intervention in the form of isiZulu supplementation. They all said that learning in isiZulu would be harder for them than learning in English. This was despite them suggesting that everyone understands better in their home language, with some of them also pointing out that they themselves often learn by first translating what they have learnt into isiZulu to understand it better, or discuss it with their fellow classmates in isiZulu.

Based on these findings, one of the main conclusions reached by the study was that the EO participants viewed language use and relevance at their institution more in terms of each language's general socioeconomic value, rather than in terms of its perceived or potential pedagogical value. The participants' arguments demonstrated that improved academic proficiency was less important for them than upward socioeconomic mobility. Their aspirations reflected what most black people throughout the African continent primarily strive for, having been excluded and repressed for centuries of white domination, and what students hope to become more able to achieve through obtaining higher education qualifications (Alexander, 2001; Phillipson, 1996; Skutnabb-Kangas, 2009). According to the EO participants who opposed the wider integration of ISALs, the primary purpose of formal education for black people is for them to become more proficient in English, which the participants regarded as the language generally known to be the most legitimate language of academia and commerce. The BZ participants, on the other hand, all stated that they found academic content taught in isiZulu much clearer and easier to understand than content taught in English. Even when questioned about their perspectives on the perceived socioeconomic implications of linguistic proficiencies and language use in South Africa, these participants repeatedly emphasised the importance of using, developing, and elevating one's own home language.

To then simply argue that black South African higher education students and lecturers are against the inclusion of ISALs in their institutions, without contextualising their perspectives within the linguistic ideologies of South Africa's sociopolitical history, seems to paint an incomplete picture. As has been found over centuries, their, and the rest of South Africa's perceptions of languages are socially constructed (Alexander, 2001; Heugh, 2000). Furthermore, it is the view of the authors that it is not enough to legitimise opposing arguments with the circular notion that English is in reality the only means for upward socioeconomic mobility while ISALs would only serve to segregate the nation and further disadvantage underprivileged black students. Instead, it is a necessary exercise to first demonstrate how none of the languages in South Africa are neutral entities but, rather, are all value-laden and perceived-based primarily on their pragmatic and symbolic power or lack thereof. This demonstration could, in turn, illuminate how any discussion regarding language in education is inextricable from linguistic ideologies and how, to some black South Africans, the former is secondary to the latter. 
In conclusion, while some of the arguments that promote linguistic transformation for higher education also try to promote endeavours for socioeconomic transformation, this paper proposes that their proponents should also acknowledge the need to address current ideological perceptions and socioeconomic processes that impede these efforts. And, while arguments against linguistic transformation for higher education illuminate the current ideological perceptions and socioeconomic processes that appear to make a wider inclusion of ISALs illogical, this perspective should also acknowledge how past ideological perceptions and socioeconomic processes created the current educational and socioeconomic landscape in the first place.

\section{Recommendations for empirical studies}

In light of the theoretical framework and study findings discussed above, the authors' recommendations for future research are, firstly, that there needs to be further research exploring the ways in which school learners and teachers, tertiary students and lecturers, as well as other stakeholders who are directly affected by language policies for education, perceive language use, relevance, and choice in South Africa-and how their perceptions affect language policy changes and implementation processes. History has shown that ideological perceptions of Western and South African indigenous languages have had a major influence on which languages are chosen for education, economic use, and development during the colonial and apartheid eras, and during the early years of the democratic era (Heugh, 2000; Skutnabb-Kangas, 2009; van Dyk, 1967). Now that government and some SAPIHEs are making concentrated efforts to elevate the use, development, and esteem of ISALs, research needs to explore the ideological perspectives nationally and institutionally that may facilitate or hinder the implementation of this inclusion. This future research should also focus on steps other countries whose indigenous languages were previously marginalised have taken to develop and elevate their respective languages' levels of esteem. One of the closest examples that could be studied is how Afrikaans was developed and elevated to the same level of use and status as English in South Africa a century ago. This should also include why, despite its official use nationally, the language's esteem amongst most black South Africans was nonetheless relegated to the point of rejection (Reagan, 1987). Research that focuses on how bilingual instruction that includes students' home languages facilitates a better acquisition of knowledge also needs to be contextualised within SAPIHEs where ISALs are now officially in the process of being used for tuition. Lastly, studies exploring the effectiveness of English language teaching to black students in the differentially equipped public schools should explore whether their English proficiencies have a significant effect on their academic performance through the end of tertiary studies.

\section{Recommendations for policy}

Reported conflicting perspectives of national and institutional language policies indicate a need for studies that explore what informs these perspectives, and how negotiations to reach agreements may be facilitated. EO participants in this study expressed great frustration with what they perceived as a lack of communication from UKZN management regarding the policy content, and implementation plans. Their insufficient knowledge regarding the content 
and rationale behind the national and institutional language policies for education seemed to have a great influence on how they perceived the value of bilingual instruction. Negative perspectives reported in the media also display the students' and community's lack of understanding of the entire contents of the national and institutional policies (NdimandeHlongwa et al., 2010; Rudwick, 2015; Taunyane, 2013). Policy evaluation needs to gauge the effectiveness of the communication of UKZN's policy with all its stakeholders within the institution and in the wider community. Some of the EO participants, for example, recommended that management could host festivals, campaigns, and discussions to establish how students perceive the policy, instead of leaving them feeling alienated. Conversely, the BZ participants appeared to be aware that it is in fact possible to develop any language and elevate its status and esteem and were, therefore, willing to learn in isiZulu and contribute towards developing and elevating it further. Some of the EO participants, on the other hand, seemed to think that the status of a language is static, implying that the current level of use of languages in this country and in the world will never change, so ISALs will always lack value and usefulness. Additionally, EO participants who recommended that students' perceptions of ISALs should be actively addressed by management and government seemed to still view this as more important for elevating the cultural and communicative significance of ISALs rather than their possible pedagogical and economic value. When considering this, perhaps if government and management in SAPIHEs made more of an effort to educate students about the past ideological constructions of languages, and how these continue to affect current ideological constructions and processes, as well as how it is possible for ISALs to gain pedagogical, economic, and social value and what it would take for this to happen, black African students might understand the importance of this much-needed reformation and would be more willing to contribute to making it happen. As Granville et al. (1998) pointed out, as admirable and well-meaning as a democratic language policy may appear, it will most likely not be readily accepted by the same black South Africans it intends to empower if they continue to perceive their languages as stigmatised, under-developed, and useless.

\section{Study limitations}

This study only explored the perceptions and perspectives of 14 black African UKZN students, selected using a non-probability snowball sampling technique. This means that their views cannot be generalised across the institution's widely diverse student body. The study findings also cannot be used to make generalisations about students outside of UKZN.

In addition, because of sampling difficulties (detailed in the first author's master's thesis; Madlala, 2018), the study did not include the perspectives of the other stakeholders at the institution, namely students of other races, lecturers, and management. Their perspectives could have further illuminated the ideological constructions and linguistic contexts that frame perspectives regarding the institution's bilingual policy. In addition, as a researcher approaching the study from an interpretive theoretical approach, the first author did not have an objective perspective of the participants' views. Her analysis of their responses is based on the assumptions of just one school of thought in this field of study. Different schools of 
thoughts in various other fields could arrive at different conclusions based on how the data is interpreted within their theoretical viewpoints.

\section{References}

Adegbite, W. (2003). Enlightenment and attitudes of the Nigerian elite on the roles of languages in Nigeria. Language, Culture and Curriculum, 16(2), 185-196. doi:10.1080/07908310308666667

Akinnaso, F. N. (1993). Policy and experiment in mother tongue literacy in Nigeria. International Review of Education, 39(4), 255-285. Retrieved from http://www.jstor.org.ukzn.idm.oclc.org/stable/pdf/3445126.pdf

Alexander, N. (2001). Language politics in South Africa. In S. Bekker, M. Dodds, \& M. M. Khosa (Eds.), Shifting African identities (pp. 141-152). Pretoria, RSA: Human Sciences Research Council.

Braun, V., \& Clarke, V. (2006). Using thematic analysis in psychology. Qualitative Research in Psychology, 3(2), 77-101. doi:10.1191/1478088706qp063oa

Bunyi, G. (1999). Rethinking the place of African indigenous languages in African education. International Journal of Educational Development, 19(4), 337-350. doi:10.1016/S0738-0593(99)00034-6

Chetty, N. (2013). Student responses to being taught physics in isiZulu. South African Journal of Science, 109(9/10), 1-6. doi:10.1590/sajs.2013/20120016

Constitution of the Republic of South Africa (1996). Constitution of the Republic of South Africa (No. 108 of 1996). Retrieved from http://www.justice.gov.za/legislation/constitution/SAConstitution-web-eng.pdf

Council on Higher Education. (2001). Language policy framework for South African higher education. Retrieved from http://www.dhet.gov.za/HED\%20Policies/Language\%20Policy\%20Framework\%20fo r\%20South\%20African\%20Higher\%20Education.pdf

Council on Higher Education. (2015). VitalStats: Public higher education 2013. Retrieved from http://www.che.ac.za/sites/default/files/publications/Vital\%20Stats\%202013_web.pdf Cummins, J. (1980). The cross-lingual dimensions of language proficiency: Implications for bilingual education and the optimal age issue. Tesol Quarterly, 14(2), 175-187. doi:10.2307/3586312

Cummins, J. (2000). Language, power and pedagogy: Bilingual children in the crossfire. Clevedon, UK: Multilingual Matters. 
Dalvit, L., \& de Klerk, V. (2005). Attitudes of Xhosa-speaking students at the University of Fort Hare towards the use of Xhosa as a language of learning and teaching (LoLT). Southern African Linguistics and Applied Language Studies, 23(1), 1-18.

Department of Bantu Education. (1962). Report of the commission of enquiry into the teaching of the official languages and the use of the mother tongue as medium of tuition in Transkeian Primary Schools. Pretoria, RSA: Author.

Elliott, A. V. P., \& Gurrey, P. (1940). Language teaching in African schools. London, UK: Longmans, Green \& Co.

Figone, K. E. (2012). The hegemony of English in South African education. Scripps Senior Theses (Paper 43). Retrieved from http://scholarship.claremont.edu/cgi/viewcontent.cgi?article=1044\&context=scripps_t heses

Granville, S., Janks, H., Joseph, M., Mphahlele, M., Ramani, E., Reed, Y., \& Watson, W. (1998). English with or without $\mathrm{g}(\mathrm{u})$ ilt: A position paper on language in education policy for South Africa. Language and Education, 12(4), 254-272. doi:10.1080/09500789808666753

Guba, E. G., \& Lincoln, Y. S. (1989). Fourth generation evaluation. Newbury Park, CA: SAGE.

Heugh, K. (2000). The case against bilingual and multilingual education in South Africa (PRAESA: Occasional Papers No. 6). Retrieved from http://www.praesa.org.za/wpcontent/uploads/2017/01/Paper6.pdf

Kyeyune, R. (2003). Challenges of using English as a medium of tuition in multilingual contexts: A view from Ugandan classrooms. Language, Culture and Curriculum, 16(2), 173-184. doi:10.1080/07908310308666666

Macdonald, C. A. (1990). Crossing the threshold into Standard Three. Pretoria, RSA: Human Sciences Research Council.

Madlala, N. (2018). University of KwaZulu-Natal's students' perceptions and perspectives on bilingual instruction at the institution (unpublished master's thesis). University of KwaZulu-Natal, Pietermaritzburg, South Africa.

Makhele, T. (2016, November 11). Does higher education promote colonisation of the Black mind? News24. Retrieved from https://www.news24.com/MyNews24/does-highereducation-promote-colonisation-of-the-Black-mind-20161111

Masitsa, M. G. (2004). Four critical causes of under-achievement in township secondary schools. Acta Academica-University of the Free State, 36, 213-245. Retrieved from https://journals-co- 
za.ukzn.idm.oclc.org/docserver/fulltext/academ/36/1/academ_v36_n1_a9.pdf?expires

$=1536638080 \& i d=i d \&$ accname $=57926 \&$ checksum $=2$ B0FE6210E58515B2283317C 3 A178FE0

Ministry of Education. (2002). Language policy for higher education. Retrieved from http://www.dhet.gov.za/Management\%20Support/Language\%20Policy\%20for\%20Hi gher\%20Education.pdf

Ndimande-Hlongwa, N., Balfour, R. J., Mkhize, N., \& Engelbrecht, C. (2010). Progress and challenges for language policy implementation at the University of KwaZulu-Natal. The Language Learning Journal, 38(3), 347-357. doi:10.1080/09571736.2010.511788

Paxton, M. (2009). "It's easy to learn when you using your mother tongue but with English you need to start learning language before you get to the concept": Bilingual concept development in an English medium university in South Africa. Journal of Multilingual and Multicultural Development, 30(4), 345-359.

Phillipson, R. (1996). Linguistic imperialism: African perspectives. ELT Journal, 50(2), 160167. doi:10.1093/elt/50.2.160

Reagan, T. G. (1987). The politics of linguistic apartheid: Language policies in Black education in South Africa. The Journal of Negro Education, 56(3), 299-312. doi:10.2307/2295225

Rudwick, S. (2015, October 1). Making an African language compulsory at university may do more harm than good. The Conversation. Retrieved from https://theconversation.com/making-an-african-language-compulsory-at-universitymay-do-more-harm-than-good-48330

Rudwick, S., \& Parmegiani, A. (2013) Divided loyalties: Zulu vis-à-vis English at the University of KwaZulu-Natal. Language Matters, 44(3), 89-107. doi:10.1080/10228195.2013.840012

Setati, M., Adler, J., Reed, Y., \& Bapoo, A. (2002). Incomplete journeys: Code-switching and other language practices in mathematics, science and English language classrooms in South Africa. Language and education, 16(2), 128-149. doi:10.1080/09500780208666824

Silverman, D. (2005). Doing qualitative research. London, UK: SAGE.

Skutnabb-Kangas, T. (2009, January). The stakes: Linguistic diversity, linguistic human rights and mother tongue based multilingual education-or linguistic genocide, crimes against humanity and an even faster destruction of biodiversity and our planet. Keynote presentation at Bamako International Forum on Multilingualism, Bamako, Mali. Retrieved from http://www.tove-skutnabb- 
kangas.org/pdf/Tove_Skutnabb_Kangas_Keynote_presentation_at_Bamako_Internati onal_Forum_on_Multilingualism_Bamako_Mali_19_21_Jan_2009.pdf

Statistics South Africa. (2013). Mid-year population estimates 2013. Retrieved from http://www.statssa.gov.za/publications/P0302/P03022013.pdf

Taunyane, O. (2013, May 17). UKZN hailed for compulsory isiZulu classes. eNCA.

Retrieved from http://www.enca.com/south-africa/isizulu-mandatory-ukzn-students

Terre Blanche, M., Kelly, K., \& Durrheim, K. (2014). Why qualitative research? In M. Terre Blanche, K. Durrheim, \& D. Painter (Eds.), Research in practice: Applied methods for the social sciences (2nd ed., pp. 271-284). Cape Town, RSA: Juta \& Co.

University of KwaZulu-Natal (UKZN). (2013). UKZN teaching \& learning annual review 2013. Retrieved from http://utlo.ukzn.ac.za/Files/UKZN\%20Teaching\%20and\%20Learning\%20Report\%20 2013.pdf

University of KwaZulu-Natal (UKZN). (2014). Language policy of the University of KwaZulu-Natal. Retrieved from http://registrar.ukzn.ac.za/Libraries/policies/Language_Policy__CO02010906.sflb.ashx

van Dyk, D. F. (1967, March). The contact between the early tribal African education and the Westernized system of missionary education. Inaugural lecture given in the University College of Fort Hare, Alice. 